\title{
PERLINDUNGAN HUKUM PARA PIHAK DALAM PERJANJIAN KERJASAMA KEMITRAAN DENGAN POLA INTI PLASMA ANTARA PT. AGRO MAKMUR SENTOSA DENGAN PETERNAK DI KABUPATEN KENDAL
}

\author{
Cicilia Prizka Dianita, Achmad Busro \\ Magister Kenotariatan, Universitas Diponegoro \\ Jl. Imam Bardjo, Pleburan, Semarang 50241 \\ e-mail : c.prizkadianita@gmail.com
}

\begin{abstract}
In an effort to realize the justice and prosperity, the government has urged people in all sectors good people business small business sector and big business sector is developing. One business sector developing in public among other venture in farm. Business in breeding having still good if efforts have special attention from the government, and the an intensive management can improve the welfare of farmers. Highlights the difficulty in this research: how the protection of the law the parties in the agreement on the core partnership between PT. Agro Makmur Sentosa with rancher in Kabupaten Kendal, how the authority of the government in the agreement on partnership of livestock enterprises. The methodology used is juridical empirical.The empirical juridical chosen for research this requires data-data in the field based on the fact that is then used to analyze and make inferences on a question. There are 2 the protection of the law plasma namely preventive and repressive measures.Performed with the preparation of the guidelines law partnership, the creation of conducive climate, counseling, supervision, give our resolve or to give relief advocacy. In running the authority in accordance with the law, health department for husbandry and animals are still less active to engage in supervising and to create farmers who is, they are too fixated on the regulation and tends to wait for such as in.
\end{abstract}

Keywords: Agreement Partnership, Breeders Partnership.

\begin{abstract}
Abstrak
Dalam usaha mewujudkan masyarakat yang adil dan makmur, pemerintah mendorong masyarakat dalam semua sektor usaha rakyat baik sektor usaha kecil maupun sektor usaha besar yang kini sedang berkembang. Salah satu sektor usaha yang sedang berkembang dalam masyarakat antara lain usaha dibidang peternakan. Usaha di bidang peternakan memiliki prospek yang baik apabila usaha tersebut memperoleh perhatian khusus dari pemerintah, serta adanya suatu pengelolaan yang intensif dapat meningkatkan kesejahteraan peternak. Permasalahan dalam penelitian ini: Bagaimana Perlindungan Hukum Para Pihak Dalam Perjanjian Kerjasama Kemitraan Inti Plasma Antara PT. Agro Makmur Sentosa Dengan Peternak Di Kabupaten Kendal, Bagaimana Kewenangan Pemerintah Dalam Perjanjian Kerjasama Kemitraan Usaha Peternakan. Metode penelitian yang digunakan adalah yuridis empiris. Pendekatan yuridis empiris dipilih karena penelitian ini memerlukan data-data yang ada di lapangan berdasarkan kenyataan yang ada yang kemudian dipergunakan untuk menganalisis dan membuat kesimpulan mengenai masalah yang diteliti. Terdapat 2 perlindungan hukum plasma yaitu preventif dan represif. Dilakukan dengan penyiapan ramburambu hukum kemitraan, penciptaan iklim yang kondusif, pembimbingan, pengawasan, memberikan penyelesaiannya atau memberikan bantuan advokasi. Dalam menjalankan
\end{abstract}


kewenangan sesuai ketentuan perundang-undangan, Dinas Peternakan dan Kesehatan Hewan masih kurang aktif untuk terlibat dalam mengawasi dan membina peternak yang ada, mereka terlalu terpaku pada peraturan dan lebih banyak menunggu laporan yang masuk.

Kata Kunci : Perjanjian Kemitraan, Inti Plasma.

\section{A. Pendahuluan}

Indonesia merupakan negara berkembang yang dikelompokkan dalam salah satu negara industri baru. Kemajuan di bidang ekonomi membuktikan bahwa Indonesia cukup sukses dalam mengadakan pembangunan nasional. Dalam usaha mewujudkan masyarakat yang adil dan makmur, pemerintah mendorong masyarakat dalam semua sektor usaha rakyat baik sektor usaha kecil maupun sektor usaha besar yang kini sedang berkembang. Salah satu sektor usaha yang sedang berkembang dalam masyarakat antara lain usaha dibidang peternakan. Usaha di bidang peternakan memiliki prospek yang baik apabila usaha tersebut memperoleh perhatian khusus dari pemerintah, serta adanya suatu pengelolaan yang intensif dapat meningkatkan kesejahteraan peternak. Selain dapat meningkatkan kesejahteraan dari peternak sendiri juga dapat membantu pemerintah membuka lapangan pekerjaan dan mengurangi tingkat pengangguran. Namun karena masih banyaknya terdapat peternak kecil maka demi mengembangkan usaha peternakannya mereka melakukan kemitraan dengan perusahaan peternakan. Kemitraan ini biasanya mengenai: penyediaan sarana produksi, pemberian bimbingan teknis, manajemen usaha dan produksi, perolehan, penguasaan, dan peningkatan teknologi yang diperlukan, pembiayaan, dan pemberian bantuan lainnya yang diperlukan bagi efisiensi dan produktifitas usaha.

Mengenai kemitraan usaha secara umum yang diatur dalam Undang-Undang Nomor 20 Tahun 2008 Tentang usaha Mikro, Kecil, dan Menengah, selain itu juga Peraturan Pemerintah Nomor 44 Tahun 1997 Tentang Kemitraan maupun kemitraan usaha peternakan yang diatur dalam Peraturan Menteri Pertanian Nomor 13/ PERMENTAN/PK.240/5/2017 Tentang Kemitraan Usaha Peternakan. Menurut Peraturan Pemerintah No. 44 tahun 1997 tentang kemitraan, Pasal 1 angka 1 menyatakan :

“Kemitraan adalah kerjasama usaha antara Usaha Kecil dengan Usaha Menengah dan atau dengan Usaha Besar disertai pembinaan dan pengembangan oleh Usaha Menengah dan atau Usaha Besar dengan memperhatikan prinsip saling memerlukan, saling memperkuat dan saling menguntungkan". 
Dalam Permentan secara lebih lanjut diatur mengenai bentuk pola-pola kerjasama kemitraan dalam Pasal 1 angka 8, 9, 10, 11, dan 12 yang meliputi pola inti plasma, pola bagi hasil, pola sewa, pola perdagangan umum, dan pola subkontrak. Namun dalam pelaksanaannya yang paling banyak diterapkan adalah pola inti plasma dimana hubungan kemitraan terjalin antara perusahaan peternakan sebagai inti dan peternak sebagai plasma. Selanjutnya dalam Pasal 11 Permentan No. 12 Tahun 2017 ini diterangkan bahwa suatu perjanjian kemitraan dilakukan dalam bentuk perjanjian tertulis, dimana perjanjian tertulis tersebut harus diketahui oleh unsur pemerintah daerah kabupaten atau kota sebagai pembina kemitraan usaha. Ketentuan ini berbeda apabila dibandingan dengan ketentuan mengenai suatu perjanjian dalam Kitab Undang-Undang Hukum Perdata dimana menurut Pasal 1313 KUH Perdata. Dalam ketentuan-ketentuan tersebut tidak menyebutkan bahwa suatu perjanjian dibuat secara tertulis seperti dalam ketentuan Pasal 11 Permentan No 13 Tahun 2017. Ketentuan dalam Kitab Undang-Undang Hukum Perdata tersebut hanya meyatakan bahwa suatu perjanjian merupakan suatu kesepakan antara satu pihak dengan pihak yang lain, dimana para pihak tersebut haruslah cakap untuk berbuat hukum dan mengenai objek perjanjian tersebut haruslah mengenai suatu hal tertentu dimana hal tersebut tidak boleh bertententangan dengan peraturan perundang-undangan, ketertiban umum dan kesusilaan.

Selain berdasarkan ketentuan diatas, mengenai suatu perjanjian tidak diwajibkan untuk harus berbentuk perjanjian juga didasarkan pada asas konsensualisme. Asas konsensualisme berasal dari kata latin consensus yang berarti sepakat. Hal tersebut berarti bahwa pada dasarnya suatu perjanian yang timbul sudah dilahirkan sejak detik tercapainya kesepakatan, atau dengan perkataan lain perjanjian itu sudah sah apabila sudah tercapai kata sepakat mengenai hal pokok dan tidak diperlukan suatu formalitas. Kecuali perjanjian formil yang merupakan perjanjian yang diharuskan secara tertulis seperti perjanjian perdamaian atau dengan akta notaris seperti perjanjian menghibahkan benda tetap(Soeroso, 2011).

Berdasarkan pada paparan di atas mengenai masih adanya perbedaan ketentuan yang mengatur mengenai perjanjian kerjasama kemitraan inti plasma dan contoh sengketa yang mungkin akan muncul dalam perjanjian kerjasama kemitraan inti plasma antara PT. Agro Makmur Sentosa dengan peternak di Kabupaten Kendal, maka melalui tesis ini penulis ingin mengetahui secara lebih jelas mengenai perlindungan hukum para pihak dalam perjanjian kerjasama kemitraan inti plasma antara PT. Agro Makmur Sentosa dengan peternak, upaya penyelesaian sengketa yang timbul dari perjanjian kerjasama kemitraan inti plasma antara PT. 
Agro Makmur Sentosa dengan peternak dan mengenai kewenangan pemerintah dalam perjanjian kerjasama kemitraan inti plasma dengan mengangkat judul "Perlindungan Hukum Para Pihak Dalam Perjanjian Kerjasama Kemitraan Dengan Pola Inti Plasma Antara PT. Agro Makmur Sentosa Dengan Peternak Di Kabupaten Kendal”. Penelitian ini membahas tentang bagaimana Perlindungan Hukum Para Pihak Dalam Perjanjian Kerjasama Kemitraan Inti Plasma Antara PT. Agro Makmur Sentosa Dengan Peternak Di Kabupaten Kendal dan bagaimana Kewenangan Pemerintah Dalam Perjanjian Kerjasama Kemitraan Usaha Peternakan.

\section{B. Metode Penelitian}

Metode pendekatan yang digunakan dalam penelitian ini adalah metode pendekatan yuridis empiris. Pendekatan yuridis empiris dipilih karena disamping melalui pendekatan yuridis, penelitian ini juga memerlukan data-data yang ada di lapangan berdasarkan kenyataan yang ada yang kemudian dipergunakan untuk menganalisis dan membuat kesimpulan mengenai masalah yang diteliti.

Spesifikasi penelitian yang digunakan dalam penelitian kali ini berupa penelitian yang bersifat diskriptif analisis yaitu penelitian yang bermaksud untuk memberikan gambaran mengenai situasi-situasi atau kejadian-kejadian tertentu untuk mengambil kesimpulan secara umum dari obyek masalahnya(Soekanto, 1986).

Berdasarkan data-data yang telah diperoleh maka dalam hal ini penulis menggunakan analisa data yang bersifat kualitatif, karena didalamnya data deskriptif analisis yang bertujuan menggambarkan secara sistematik dan akurat mengenai fakta dan karakteristik populasi atau bidang tertentu(Suharsimi, 1998).

\section{Hasil dan Pembahasan}

\section{Perlindungan Hukum Para Pihak Dalam Perjanjian Kerjasama Kemitraan Usaha}

\section{Peternakan}

Perlindungan hukum plasma yang diklasifikasikan ke dalam 2 (dua) kelompok yaitu preventif dan represif.

\section{Preventif}

Tujuan dari perlindungan dengan pola preventif tersebut memberikan jaminan perlindungan hukum yang sebenarnya tidak hanya untuk plasma tetapi juga untuk pihak inti, yaitu dengan cara: (dari pemerintah) 
a. Penyiapan rambu-rambu hukum kemitraan yang mana dalam hal ini adalah Peraturan Perundang-undangan mengenai Kemitraan Usaha Peternakan yang kemudian didalamnya juga mengatur tentang perjanjian kerjasama kemitraan usaha peternakan baik mengenai syarat maupun klausul-klausul yang harus dimuat didalamnya.

b. Penciptaan iklim yang kondusif meliputi langkah-langkah untuk menciptakan persaingan yang sehat dan sejauh mungkin mencegah timbulnya keadaan yang merugikan perekonomian nasional yang harus diartikan sebagai upaya pemerintah dalam serangkaian kebijakan hukum ekonomi nasional maupun internasional yang mendukung kebijakan di bidang kemitraan. Penciptaan iklim tersebut dapat dilakukan melalui jalur hukum, kebijakan ekonomi yang bersifat makro maupun mikro ekonomi seperti pemberian kemudahan-kemudahan dalam proses-proses kemitraan, pemberian insentif-insentif bagi pengusaha besar yang melaksanakan kemitraan ini. (Pasal 11 Peraturan Pemerintah Nomor 44 Tahun 1997)

c. Pembinaan kemitraan usaha peternakan dilakukan untuk meningkatkan kesetaraan yang saling memerlukan, memperkuat, menguntungkan, menghargai, bertanggung jawab, dan ketergantungan dalam pengembangan usaha peternakan. Pembinaan kemitraan dilakukan oleh Perusahaan Peternakan, bupati/wali kota, gubernur, dan Menteri dalam pengembangan usaha peternakan sesuai dengan pola kemitraan (Pasal 22 Peraturan Pemerintah Nomor 44 Tahun 1997 dan Pasal 12 Peraturan Menteri Pertanian Republik Indonesia Nomor 13/ PERMENTAN/PK.240/5/2017 Tentang Kemitraan Usaha Peternakan)

d. Pengawasan kemitraan usaha peternakan dapat dilakukan secara langsung atau tidak langsung. Pengawasan secara langsung dilakukan melalui peninjauan ke lokasi Kemitraan Usaha Peternakan dan dilakukan paling kurang selama 6 (enam) bulan sekali. Sedangkan Pengawasan secara tidak langsung dilakukan melalui penyampaian laporan pelaksanaan Kemitraan Usaha Peternakan. (Pasal 14 Peraturan Menteri Pertanian Republik Indonesia Nomor 13/ PERMENTAN/PK.240/5/2017 Tentang Kemitraan Usaha Peternakan)

Selain dengan cara diatas maka untuk mencegah terjadinya hal-hal yang merugikan usaha kecil/ plasma dalam pelaksanaan kerjasama, maka menurut Pasal 14 Peraturan Pemerintah Nomor 44 Tahun 1997, pihak inti melakukan penyuluhan dan bimbingan dalam beberapa aspek antara lain aspek pemasaran, aspek pembinaan dan pengembangan sumber daya manusia, aspek permodalan, aspek manajemen, aspek teknologi, dan lain-lain. 


\section{Represif}

Tujuan dari pola represif dalam rangka perlindungan hukum terhadap plasma adalah untuk mengetahui permasalahan-permasalahan dan memberikan penyelesaiannya atau memberikan bantuan advokasi terutama kepada plasma apabila menghadapi permasalahan yang berkaitan dengan perjanjian (Pasal 22 Pemerintah Nomor 44 Tahun 1997) dan Pasal 19 SK Menteri Nomor 472 Tahun 1996. Karena dalam praktek sangat mungkin terjadi hal-hal yang diluar jangkauan hukum atau perjanjian kemitraan itu sendiri.

\section{Kewenangan Pemerintah Dalam Perjanjian Kerjasama Kemitraan Usaha Peternakan}

\section{Koordinasi}

Sebagai lembaga yang melakukan koordinasi sebenarnya tidak hanya dari unsur pemerintah tetapi juga meliputi dunia usaha, perguruan tinggi dan tokoh masyarakat (Pasal 26 Peraturan Pemerintah Nomor 44 Tahun 1997). Di dalam melakukan koordinasi ruang lingkupnya meliputi kegiatan dalam hal penyusunan kebijaksanaan dan program pelaksanaan, pemantauan dan evaluasi serta pengendalian umum terhadap pelaksanaan kemitraan usaha nasional.

\section{Pembinaan}

Pembinaan kemitraan usaha peternakan dilakukan untuk meningkatkan kesetaraan yang saling memerlukan, memperkuat, menguntungkan, menghargai, bertanggung jawab, dan ketergantungan dalam pengembangan usaha peternakan. Pembinaan kemitraan dilakukan oleh Perusahaan Peternakan, bupati/wali kota, gubernur, dan Menteri dalam pengembangan usaha peternakan sesuai dengan pola kemitraan. Selain itu pembinaan juga dapat dilakukan bersama kementerian dan/atau lembaga lain yang terkait. Pem binaan kemitraan yang dilakukan oleh Menteri dalam pelaksanaannya dilakukan oleh Direktur Jenderal Peternakan dan Kesehatan Hewan. Pembinaan kemitraan yang dilakukan oleh gubernur dalam pelaksanaannya dilakukan oleh kepala SKPD provinsi atau pejabat yang ditunjuk. Pembinaan kemitraan yang dilakukan oleh bupati/ wali kota dalam pelaksanaannya dilakukan oleh kepala SKPD kabupaten/ kota atau pejabat yang ditunjuk. Pembinaan kemitraan yang dilakukan oleh menteri dan/atau pimpinan lembaga lain yang terkait dilakukan sesuai dengan ketentuan peraturan perundang-undangan.

\section{Pengawasan}

Program kemitraan sebagai kebijakan hukum yang diamanatkan oleh GBHN Republik Indonesia tahun 1999, dalam pelaksanaannya tentunya tidak dapat dilaksanakan begitu saja tanpa peran serta dari pemerintah. Sebagaimana dalam ketentuan dalam Pasal 23 Peraturan Pemerintah Nomor 44 Tahun 1997 tentang Kemitraan yang menyatakan sebagai berikut: 
"Menteri teknis bertanggungjawab memantau dan mengevaluasi pembinaan pengembangan pelaksanaan kemitraan usaha sesuai dengan bidang tugasnya masing-masing."

Mengenai pengawasan dalam kemitraan secara lebih rinci dijabarkan dalam Peraturan Menteri Pertanian Republik Indonesia (PERMENTAN) Nomor 13 Tahun 2017 Tentang Kemitraan Usaha Peternakan pada Pasal 14 sampai dengan Pasal 17 dijelaskan bahwa Pengawasan Kemitraan Usaha Peternakan dapat dilakukan secara langsung atau tidak langsung. Pengawasan secara langsung dilakukan melalui peninjauan ke lokasi Kemitraan Usaha Peternakan dan dilakukan paling kurang selama 6 (enam) bulan sekali. Sedangkan Pengawasan secara tidak langsung dilakukan melalui penyampaian laporan pelaksanaan Kemitraan Usaha Peternakan.

Pengawasan Kemitraan Usaha Peternakan dilakukan oleh Menteri, gubernur, dan bupati/wali kota sesuai dengan kewenangannya. Pengawasan kemitraan oleh Menteri sebagaimana dimaksud, pelaksanaannya dilakukan oleh Direktur Jenderal Peternakan dan Kesehatan Hewan. Mengenai Pengawasan kemitraan oleh gubernur pelaksanaannya dilakukan oleh kepala SKPD provinsi. Sedangkan mengenai Pengawasan kemitraan oleh bupati/wali kota pelaksanaannya dilakukan oleh kepala SKPD kabupaten/kota.

Isi ketentuan pasal di atas jelas memberkan amanat kepada menteri teknis untuk melakukan pengawasan dan pengendalian kemitraan, dimana dalam hal ini dilaksanakan oleh Direktur Jenderal Peternakan dan Kesehatan Hewan.

Pemerintah sebagai pelaksana kemitraan tentunya meliputi aspek-aspek kegiatan kebijakan hukum pada umumnya yaitu: Formulating; Executing; Controling. Ketiga tahap kebijakan bidang kemitraan tersebut tentunya tidak bisa berjalan sendiri-sendiri, dan kesemuanya menjadi variable pengaruh (independent variable) dan sekaligus variabel terpengaruh (dependent variable). Fungsi formulasi tertentu sangat ditentukan dengan model pelaksanaan (executing) ataupun model pengawasan (controlling) yang akan dijalankan dan demikian pula sebaliknya. Khususnya dalam masalah controling dapat diartikan sebagai pengawasan namun dalam sisi lain dapat pula diartikan sebagai pengendalian, fungsi pengawasan lebih menekankan kepada kegiatan yang tidak aktif sedangkan pengendalian sebenarnya merupakan pengawasan dalam bentuk kegiatan aktif. Fungsi-fungsi pengawasan dan atau pengendalian ini dilakukan dalam beberapa tahapan proses gabungan antara pengawasan dan pengendalian yang dalam kepustakaan manajemen terdiri:

a. Pra Pengawasan (preliminary control) 
Pra pengawasan pelaksanaan (preliminary control) atau pengawasan preventif dengan tujuan untuk mempersiapkan kebijakan hukum serta pengendalian pra pelaksanaan kebijakan kemitraan yang dapat memberikan jaminan perlindungan hukum bagi calon pelakunya, baik pengusaha besar sebagai inti, plasma maupun pengusaha kecil. Pengawasan preventif ini diwujudkan dalam beberapa tindakan seperti:

1) Penyiapan rambu-rambu hukum kemitraan

2) Penciptaan iklim yang kondusif (Pasal 11 Peraturan Pemerintah Nomor 44 Tahun 1997)

3) Pembinaan (Pasal 22 Peraturan Pemerintah Nomor 44 Tahun 1997 dan Pasal 12 Peraturan Menteri Pertanian Republik Indonesia Nomor 13/ PERMENTAN/PK.240/5/2017 Tentang Kemitraan Usaha Peternakan)

Penyiapan rambu-rambu hukum kemitraan tentunya sangat penting dalam proses pengawasan dan pengendalian kemitraan, sebab bagaimanapun bentuk usaha kemitraan tentunya pelaksanaannya berpulang kepada perjanjian kemitraan itu sendiri. Kesalahan atau kekurang akuratan dalam pembuatan perjanjian hukum kemitraan tentu sangat rentan menimbulkan permasalahan di kemudian hari. Mengingat pentingnya aspek perjanjian serta rambu-rambu hukum dalam masalah kemitraan, maka pemerintah dalam hal ini Dinas Peternakan dan Kesehatan Hewan melakukan pembatasan-pembatasan, pelarangan atau bahkan dispensasidispensasi yang tujuan akhirnya adalah memberikan perlindungan hukum baik para pihak dalam kemitraan. Penciptaan iklim yang kondusif, harus diartikan sebagai upaya pemerintah dalam serangkaian kebijakan hukum ekonomi nasional maupun internasional yang mendukung kebijakan di bidang kemitraan. Penciptaan iklim tersebut dapat dilakukan melalui jalur hukum, kebijakan ekonomi yang bersifat makro maupun mikro ekonomi seperti pemberian kemudahankemudahan dalam proses-proses kemitraan, pemberian insentif-insentif bagi pengusaha besar yang melaksanakan kemitraan ini sebagaimana diatur dalam Pasal 11 Peraturan Pemerintah Nomor 44 Tahun 1997 sebagai berikut:

"Untuk lebih mendorong terwujudnya kemitraan antara usaha besar dan atau usaha menengah dengan usaha kecil, terhadap kemitraan yang berlangsung diberikan perlakuan tambahan sebagai berikut:

a) Pengutamaan kesempatan diberi kelonggaran untuk pengadaan barang dan jasa yang diperlukan pemerintah; 
b) Dalam hal-hal tertentu diberi kelonggaran untuk memanfaatkan bidang usaha yang dicadangkan untuk usaha kecil;

c) Pengeluaran dalam rangka pembinaan dan pengembangan kemitraan dipertimbangkan sebagai biaya yang dapat dikurangkan dari penghasilan bruto dalam rangka penentuan besarnya Penghasilan Kena Pajak bagi usaha besar dan atau usaha menengah yang bersangkutan."

Pembinaan sebagai salah satu kegiatan pengawasan dan pengendalian preventif sangat dibutuhkan terutama bagi usaha kecil, karena pembinaan ini bertujuan untuk menyiapkan usaha kecil dalam segala aspek untuk siap melaksanakan perjanjian kemitraan. Apabila tidak dilakukan pembinaan dalam segala aspek sangat mungkin sekali program kemitraan ini justru akan menjadi bumerang bagi usaha kecil itu sendiri. Proses pembinaan ini sendiri tidak selalu harus dilakukan oleh pemerintah, tetapi dapat saja dilakukan oleh lembaga-lembaga pendukung, sebagaimana diatur dalam Pasal 22 Peraturan Pemerintah Nomor 44 Tahun 1997, sebagai berikut:

"Lembaga pendukung lain berperan mempersiapkan dan menjembatani usaha kecil yang akan bermitra dengan usaha besar dan atau usaha menengah melalui:

a) Penyediaan informasi, bantuan manajemen dan teknologi terutama kepada usaha kecil.

b) Persiapan usaha kecil yang potensial untuk bermitra.

c) Pemberian bimbingan dan konsultasi kepada usaha kecil.

d) Pelaksanaan advokasi kepada berbagai pihak untuk kepentingan usaha kecil

e) Pelatihan dan praktek kerja bagi usaha kecil yang akan bermitra."

\section{b. Pengawasan yang bersamaan (concurrent control)}

Pengawasan yang bersamaan harus diartikan sebagai rangkaian kegiatan pengawasan dan pengendalian baik secara langsung atau tidak langsung. Pengawasan secara langsung dilakukan melalui peninjauan ke lokasi Kemitraan Usaha Peternakan dan dilakukan paling kurang 6 (enam) bulan sekali. Sedangkan pengawasan secara tidak langsung dilakukan melalui penyampaian laporan pelaksanaan kemitraan usaha peternakan kepada dinas peternakan dan kesehatan hewan sebagaimana diatur dalam Pasal 17 PERMENTAN RI Nomor 13 Tahun 2017. c. Pengawasan umpan balik (feed back control) 
Pengawasan ini diartikan sebagai serangkaian kegiatan yang tujuannya melakukan pengawasan dan pengendalian terhadap kemungkinan-kemungkinan negatif yang mungkin terjadi dalam kegiatan kemitraan, sebab dalam praktek sangat mungkin terjadi hal-hal yang diluar jangkauan hukum atau perjanjian kemitraan itu sendiri. Peran pemerintah dalam menghadapi kemungkinan negatif yang bersifat umpan balik ini diantaranya dapat dilakukan dengan memberikan bantuan advokasi terutama kepada usaha kecil apabila menghadapi permasalahan yang berkaitan dengan perjanjian. Pada sisi lain hasil pengawasan secara umpan balik ini tentunya bermanfaat untuk memberikan masukan-masukan bagi penyesuaian dan penyempurnaan kebijakan-kebijakan di bidang kemitraan di masa mendatang. Namun, karena Dinas Peternakan kurang terlibat dalam pelaksanaan pengawasan, hal tersebut berdampak pada kekurang tahuan pihak dinas mengenai permasalahan yang terjadi, sehingga mereka pada akhirnya tidak dapat memberikan kontribusi maksimal bagi penyempurnaan kebijakankebijakan di bidang kemitraan.

Secara umum dapat dikatakan bahwa dalam menjalankan kewenangannya sesuai ketentuan perundang-undangan, Dinas Peternakan dan Kesehatan Hewan kurang proaktif dalam melakukan pengawasan dan pembinaan. Menurut penulis, dinas masih kurang aktif untuk terjun langsung dalam masyarakat untuk ikut ambil bagian dalam mengawasi dan membina peternak yang ada, mereka terlalu terpaku pada peraturan dan lebih banyak menunggu laporan yang masuk. Dinas tidak mengetahui jumlah pasti peternak yang ada di Kabupaten Kendal, perusahaan-perusahaan yang melakukan kerjasama dengan peternak di Kendal. Bahkan, dinas tidak mengetahui perihal adanya organisasi PPN (Pinsar Petelur Nasional) yang merupakan satu-satunya organisasi peternakan ayam petelur di Indonesia. Berdasarkan wawancara penulis dengan peternak di Kabupaten Kendal, peternak berpendapat bahwa "Dinas Peternakan terlambat mengikuti perkembangan peternakan”. Dalam berbagai hal, dinas dianggap kurang mumpuni untuk menyelesaikan persoalan peternak. Hal ini mereka sampaikan bukan tanpa alasan karena dalam beberapa persoalan yang terjadi dinas selalu menjadi yang terakhir tanggap untuk ikut campur. Misalnya dalam hal wabah penyakit flu burung sedang banyak menjangkit peternakan di Indonesia, disaat sudah banyak laporan kasus kematian, Dinas Peternakan baru mulai terjun ke lapangan.

\section{Simpulan}


Perlindungan hukum para pihak dalam perjanjian kerjasama kemitraan usaha peternakan diklasifikasikan ke dalam 2 (dua) kelompok yaitu preventif dan represif. Perlindungan preventif merupakan perlindungan yang diberikan oleh pemerintah dengan tujuan untuk mencegah terjadinya pelanggaran yang dilakukan oleh para pihak serta memberikan rambu-rambu atau batasan-batasan kepada para pihak dalam melakukan kemitraan sehingga dapat memberikan jaminan perlindungan hukum yang sebenarnya tidak hanya untuk plasma tetapi juga untuk pihak inti, yaitu dengan cara: Penyiapan rambu-rambu hukum kemitraan; Penciptaan iklim yang kondusif; memberikan pembinaan dan pengawasan terhadap pelaksanaan kemitraan usaha peternakan. Sedangkan perlindungan hukum represif merupakan perlindungan akhir berupa tanggung jawab perusahaan, denda, penjara, dan hukuman tambahan yang diberikan apabila sudah terjadi sengketa atau pelaku usaha melakukan pelanggaran. Diaturnya suatu perjanjian kemitraan agar dilakukan secara tertulis dan dilaporkan kepada pemerintah dimaksudkan untuk mengurangi pelanggaran dan meminimalisir adanya praktek persaingan usaha tidak sehat. Namun dalam pelaksanaannya perjanjian kerjasama kemitraan inti plasma ini menggunakan kerjasama lisan maka perlindungan hukum yang diberikan pemerintah melalui peraturan perundang-undangan kurang dapat terlaksana dengan baik.

Kewenangan Pemerintah Dalam Kemitraan adalah melakukan koordinasi, pembinaan dan pengawasan Kemitraan Usaha Peternakan Namun dalam menjalankan kewenangan sesuai ketentuan perundang-undangan, Dinas Peternakan dan Kesehatan Hewan selaku wakil dari pemerintah yang diberi kewengaan berdasarkan Peraturan Menteri Pertanian Republik Indonesia Nomor 13/PERMENTAN/PK.240/5/2017 Tentang Kemitraan Usaha Peternakan, masih kurang proaktif dalam melakukan pengawasan dan pembinaan. Menurut penulis, dinas masih kurang aktif untuk terjun langsung dalam masyarakat untuk ikut ambil bagian dalam mengawasi dan membina peternak yang ada, mereka terlalu terpaku pada peraturan dan lebih banyak menunggu laporan yang masuk. Dinas tidak mengetahui jumlah pasti peternak yang ada di Kabupaten Kendal, perusahaan-perusahaan yang melakukan kerjasama dengan peternak di Kendal. Bahkan, dinas tidak mengetahui perihal adanya organisasi PPN (Pinsar Petelur Nasional) yang merupakan satu-satunya organisasi peternakan ayam petelur di Indonesia. Berdasarkan wawancara penulis dengan peternak di Kabupaten Kendal, peternak berpendapat bahwa "Dinas Peternakan terlambat mengikuti perkembangan peternakan". Dalam berbagai hal, dinas dianggap kurang mumpuni untuk menyelesaikan persoalan peternak. Hal ini mereka sampaikan dengan alasan 
bahwa dalam beberapa persoalan yang terjadi dinas selalu menjadi yang terakhir tanggap untuk ikut campur.

\section{DAFTAR PUSTAKA}

Soekanto, S. (1986). Pengantar Penelitian Hukum. Jakarta: Universitas Indonesia Press. Soeroso, R. (2011). Perjanjian Di Bawah Tangan. Jakarta: Sinar Grafika.

Suharsimi, A. (1998). Prosedur Penelitian Suatu Pendekatan Praktek. Jakarta: Rineka Cipta. 